Section Editors

David C. Spencer, MD

Steven Karceski, MD

Steven Karceski, MD

Alison Pack, MD

\title{
Seizure medications, pregnancy, and breastfeeding
}

WHAT WAS THE STUDY ABOUT? Dr. Meador and the NEAD Study Group ${ }^{1}$ looked at the same group of women (and their children) as in the published 2009 study. $^{2}$ The women had been enrolled into the study between 1999 and 2004. The children had reached age 3 , and had been exposed to one of the following seizure medications during pregnancy and breastfeeding: carbamazepine, lamotrigine, phenytoin, and valproate. To answer the question about breastfeeding, Dr. Meador compared the children who had been breastfed to those who had not. As in the 2009 study, the mother had to be taking only one medication. If taking more than one medicine, the women could not be studied. Otherwise, if there was a problem, it would be impossible to know which medication had caused the problem.

WHO DID THE AUTHORS STUDY? Dr. Meador excluded some women and their children from the study. Because other medical problems can sometimes affect the baby, women who were HIV-positive or had diabetes were not studied. Since illegal drugs might affect the baby as well, women who used illegal drugs were also excluded. When this was done, there were 199 children born to 194 mothers (there were 5 sets of twins). Overall, $42 \%$ of moms elected to breastfeed their children. The percentage of women taking each medication who breastfed was about the same. A total of $44 \%$ of women were taking carbamazepine, $46 \%$ lamotrigine, $42 \%$ phenytoin, and $32 \%$ valproate.

WHAT WERE THE RESULTS? When the two groups were compared, the answer was straightforward: exposing the baby to medication from breast milk causes no additional problems.

Of course, no study is perfect. The results were found in a relatively small number of people. If the group had been larger, the results might have been different. The amount of medication that a person takes affects the baby during pregnancy. This may also be true during breastfeeding. However, it is difficult to measure the amount of medicine a baby gets from breastfeeding. Unless the milk was taken out and placed in a bottle to be measured, there is no way to know how much milk (and therefore amount of medicine) the baby may have received. In addition, the amount of medication in the milk varied from person to person. The NEAD Study was not designed to measure exact concentrations of medicine in a person's breast milk. Finally, there are many more medications for seizures than the 4 that were studied. Whether any of these during breastfeeding could be a problem is unknown.

WHY WOULD EXPOSURE TO MEDICATIONS DURING PREGNANCY BE DIFFERENT THAN DURING BREASTFEEDING? One answer is that the brain forms during pregnancy. After the baby is born, the brain has formed, but continues to grow in size. This information supports the idea that exposure to medications during this very important period has the greatest impact on later intelligence. Second, the amount of medicine that the baby gets is higher when in the womb than when breastfed. For most medications, the concentration of medication is lower in breast milk than in the mother's bloodstream. In other words, another reason that breast milk may not cause problems is that the amount of medication is smaller.

WHAT DID THE AUTHORS CONCLUDE? No single study could ever answer all of the questions that future parents might have. With studies like NEAD, however, at least some of the answers are emerging. Neither carbamazepine, lamotrigine, phenytoin, nor valproate exposure during breastfeeding has an effect on IQ at age 3. When the NEAD study is completed, doctors will also know if IQ is affected by age 6. It is only with continued research that doctors will be able to counsel women with epilepsy about the safest medications to take during pregnancy and through breastfeeding.

WHAT DOES THIS STUDY MEAN TO ME? Everyone who starts a family has fears and concerns. How will the pregnancy go? Will the mother have problems? Will the baby be healthy and happy? All parents want their children to be intelligent and successful, and to contribute in some way to the community.

Women with epilepsy have additional fears. How will my seizures affect the baby while in the womb? 


\begin{tabular}{|c|c|c|c|}
\hline Table & e medications and breast milk & & \\
\hline $\begin{array}{l}\text { Seizure } \\
\text { medications }\end{array}$ & Present in breast milk? & $\begin{array}{l}\text { Usual blood levels } \\
\text { (in mother) }\end{array}$ & $\begin{array}{l}\text { Plasma:milk } \\
\text { ratio }^{\mathrm{a}}\end{array}$ \\
\hline Carbamazepine & Yes & $400-1,200 \mathrm{mg} / \mathrm{day}$ & $0.4-0.6$ \\
\hline Clonazepam & $\begin{array}{l}\text { Yes (recommended that women } \\
\text { not breastfeed) }\end{array}$ & $1.5-20 \mathrm{mg} /$ day & \\
\hline Clorazepate & $\begin{array}{l}\text { Yes (recommended that women } \\
\text { not breastfeed) }\end{array}$ & $15-60 \mathrm{mg} /$ day & \\
\hline Diazepam & Yes & $2-10 \mathrm{mg} / \mathrm{day}$ & \\
\hline Ethosuximide & Yes & & 0.9 \\
\hline Felbamate & $\begin{array}{l}\text { Yes (recommended that women } \\
\text { not breastfeed) }\end{array}$ & $1,200 \mathrm{mg} /$ day & \\
\hline Gabapentin & Yes & $300-1,800 \mathrm{mg} /$ day & $0.7-1.3$ \\
\hline Lamotrigine & Yes & $50-500 \mathrm{mg} /$ day & $0.4-0.7$ \\
\hline Levetiracetam & Yes & $500-5,000 \mathrm{mg} / \mathrm{day}$ & $0.85-1.55$ \\
\hline Oxcarbazepine & Yes & $300-2,400 \mathrm{mg} / \mathrm{day}$ & 0.5 \\
\hline Phenobarbital & Yes & $\begin{array}{l}50-100 \mathrm{mg} 2-3 \\
\text { times daily }\end{array}$ & $0.4-0.6$ \\
\hline Phenytoin & Yes & $300-600 \mathrm{mg} /$ day & $0.28-0.45$ \\
\hline Pregabalin & Undetermined & $75-900 \mathrm{mg} /$ day & \\
\hline Primidone & Yes & & $0.7-0.9$ \\
\hline Tiagabine & Undetermined & $2-24 \mathrm{mg} /$ dose & \\
\hline Topiramate & $\begin{array}{l}\text { Yes in rats (not evaluated } \\
\text { in human milk) }\end{array}$ & $50-400 \mathrm{mg} /$ day & $0.7-1.1$ \\
\hline Valproic acid & Yes & $50-100 \mathrm{pg} / \mathrm{mL}$ & 0.42 \\
\hline Zonisamide & Undetermined & $100-600 \mathrm{mg} / \mathrm{day}$ & 0.9 \\
\hline
\end{tabular}

a The plasma:milk ratio is a measure of how much medication is in breast milk compared to the mother's bloodstream. A ratio of 1 means that there is exactly the same amount of medication in the breast milk as in the mother's blood. A ratio of $<1$ means that there is less medication in milk than in the mother's blood. Not all medications are listed. The table is incomplete in that there are a few instances where the information is not known or is unclear. tion of the lungs (like certain lung infections and asthma), less problems with their skin (such as atopic dermatitis), and fewer problems with stomach infections (gastroenteritis). Breastfed children also seem to have a lower incidence of chronic illness like diabetes and leukemia. ${ }^{1}$

Breastfeeding may help the mother as well. Breastfeeding increases levels of a certain hormone in the body called oxytocin. The production of oxytocin helps the new mother to recover faster from labor and delivery. It does this by decreasing the amount of blood that is lost from the uterus after delivery. Breastfeeding has significant social and economic benefits to the United States. Because breastfeeding decreases certain illnesses, it also decreases health care costs. This also affects the new mothers and fathers, since they miss fewer days at work due to their child's illness. ${ }^{5}$

Even though there are benefits to breastfeeding, new parents are understandably worried that the baby will be getting some of the seizure medication in the breast milk (table). The amount of breast milk that is transferred into the milk depends on several factors. For instance, the concentration of the medication in the mother's blood partly determines how much will be in the breast milk. If the mother has a high amount of medication in her blood, this will mean that there is more medication in her breast milk. In addition, the amount of medication that a baby receives depends on how much breast milk he or she drinks. Finally, the amount of medication that is in the baby's bloodstream will depend on how quickly the baby can eliminate the medication.

Mothers with epilepsy face many challenges. Because of the concern about transfer of medication in breast milk, many mothers with epilepsy choose not to breastfeed. However, there have been no studies (until now) that have been able to specifically address this issue.

All of these are important questions. Previous Patient Pages have tried to provide answers to at least some of these questions. Of course, one Patient Page cannot answer them all. In addition, some of these questions have no clear answer. However, research like that described in the article presented here, by Dr. Meador and colleagues, begins to inform us about antiseizure medications and breastfeeding. 
Section Editors

David C. Spencer, MD

Steven Karceski, MD

\section{About epilepsy and pregnancy}

Right now, there is research going on around the world to better answer some of these questions. For instance, there are pregnancy registries around the world that are gathering information on pregnant women with epilepsy. Although some answers have started to emerge, much research is needed before doctors can answer one of the most important questions asked by parents: what medication is safe to use during pregnancy?

Problems that occur during pregnancy are not always visible. Although some medications cause birth defects that can be found when the baby is born, some problems are more difficult to detect. For instance, if a medication caused problems with thinking, how would this be measured? In fact, this is the very problem that Dr. Meador and colleagues have been trying to address. ${ }^{1,2}$ In order to do this, Dr. Meador has spent many years carefully studying women with epilepsy, the medications they are taking while pregnant, and the effects that the medications have on the developing baby.

Starting before 1999, Dr. Meador initiated the NEAD Study Group. His idea was simple: to figure out which seizure medications affect the developing baby's brain. Although a simple question, trying to answer this is very difficult. For instance, there are many factors that might influence the results. Did the mother smoke during the pregnancy? Were there other medical problems that could have affected the baby? Also, where does intelligence come from? Is it inherited from both parents? One interesting answer is that a baby's intelligence comes more from the mother than the father. ${ }^{2}$ Knowing this, Dr. Meador and the NEAD Study Group also carefully measured the mother's intelligence.

In order to best study the child's intelligence, Dr. Meador and colleagues decided to follow the children to age 6. In 2009, they published results on children who had reached age $3 .^{2}$ They analyzed results for 4 commonly used medications: carbamazepine, lamotrigine, phenytoin, and valproate. What they found was that the intelligence of the babies exposed to 3 of the drugs was unaffected. In other words, it looked like carbamazepine, lamotrigine, and phenytoin had no effect on the baby's intelli- gence. Valproate was the one that stood out: babies exposed to valproate had a lower IQ than those who had not been exposed. In addition, it seemed that the amount of valproate that the mother took was important. The more medication that the mother took during pregnancy, the more the baby's IQ was affected. Knowing this, women are counseled to change from valproate to another medication during pregnancy if this is possible.

Would a switch be possible? This depends on the person and the kind of seizures she has. Previous $\mathrm{Pa}-$ tient Pages have discussed problems that seizures during pregnancy might cause. The bottom line is that certain kinds of seizures must be controlled during pregnancy. For some women, the best control occurs when they take valproate.

So what happens after the baby is born? The baby has already been exposed to a seizure medication while he or she was in the womb. If a woman with epilepsy decides to breastfeed, will exposing the baby to seizure medication cause even more problems? Until now, it has been very difficult to answer this question. Because the answer has been vague, many women with epilepsy, wanting to protect their child from further exposure to medication, have decided not to breastfeed. Is this the correct answer? How do we weigh these concerns against the known benefits of breastfeeding?

\section{REFERENCES}

1. Meador KJ, Baker GA, Browning N, et al, for the NEAD Study Group. Effects of breastfeeding in children of women taking antiepileptic drugs. Neurology 2010;75: 1954-1960.

2. Meador KJ, Baker GA, Browning N, et al, for the NEAD Study Group. Cognitive function at 3 years of age after fetal exposure to antiepileptic drugs. N Engl J Med 2009; 360:1597-1605.

3. Li R, Zhao Z, Mokdad A, Barker L, Grummer-Strawn L. Prevalence of breastfeeding in the United States: the 2001 National Immunization Survey. Pediatrics 2003;11:11981201.

4. American Academy of Pediatrics. Policy statement: organization principles to guide and define the child health care system and/or improve the health of all children: section on breastfeeding. Pediatrics 2005;115:496-506.

5. Breastfeeding and the use of human milk. American Academy of Pediatrics 1997;100:1035-1039. 


\title{
Neurology
}

\author{
Seizure medications, pregnancy, and breastfeeding \\ Steven Karceski and Alison Pack \\ Neurology 2010;75;e90-e92 \\ DOI 10.1212/WNL.0b013e318202f559
}

This information is current as of November 29, 2010

\section{Updated Information \& Services}

\section{References}

Subspecialty Collections

Permissions \& Licensing

Reprints including high resolution figures, can be found at: http://n.neurology.org/content/75/22/e90.full

This article cites 5 articles, 1 of which you can access for free at: http://n.neurology.org/content/75/22/e90.full\#ref-list-1

This article, along with others on similar topics, appears in the following collection(s):

All Epilepsy/Seizures

http://n.neurology.org/cgi/collection/all_epilepsy_seizures Antiepileptic drugs

http://n.neurology.org/cgi/collection/antiepileptic_drugs

Information about reproducing this article in parts (figures,tables) or in its entirety can be found online at:

http://www.neurology.org/about/about_the_journal\#permissions

Information about ordering reprints can be found online:

http://n.neurology.org/subscribers/advertise

Neurology ${ }^{\circledR}$ is the official journal of the American Academy of Neurology. Published continuously since 1951, it is now a weekly with 48 issues per year. Copyright Copyright (? 2010 by AAN Enterprises, Inc.. All rights reserved. Print ISSN: 0028-3878. Online ISSN: 1526-632X.

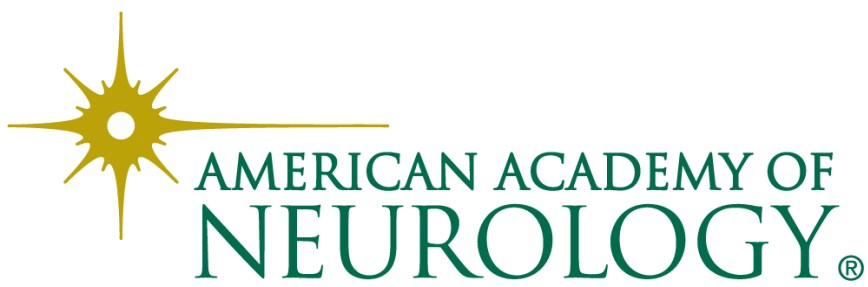

